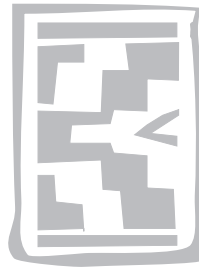

\title{
Species composition and geographic distribution of ticks infesting cattle, goats and dogs in a temperate and in a subtropical region of south-east Africa
}

\author{
I.G. HORAK ${ }^{1 *}$, N. NYANGIWE ${ }^{2}$, C. DE MATOS ${ }^{3}$ and L. NEVES ${ }^{4}$
}

\begin{abstract}
HORAK, I.G., NYANGIWE, N., DE MATOS, C. \& NEVES, L. 2009. Species composition and geographic distribution of ticks infesting cattle, goats and dogs in a temperate and in a subtropical region of south-east Africa. Onderstepoort Journal of Veterinary Research, 76:263-276

The species and distribution of ticks infesting cattle, goats and dogs in the eastern region of the Eastern Cape Province, South Africa and Maputo Province, Mozambique were determined from collections made from these animals at 72 localities in the former region and 30 in the latter. Eleven ixodid and one argasid species were recovered in the Eastern Cape Province and 15 ixodid species in Maputo Province. The most common ticks infesting cattle and goats in both provinces were Amblyomma hebraeum, Rhipicephalus (Boophilus) microplus, Rhipicephalus appendiculatus and Rhipicephalus evertsi evertsi. The dominant species on dogs were Haemaphysalis elliptica and Rhipicephalus simus. The geographic distributions of the major species and some of the minor species in both regions were plotted. The partial or complete displacement of the indigenous tick Rhipicephalus (Boophilus) decoloratus by the introduced species $R$. (B.) microplus was a major feature of both surveys.
\end{abstract}

Keywords: Cattle, dogs, Eastern Cape Province, geographic distribution, goats, ixodid ticks, Maputo Province, Mozambique, South Africa

* Author to whom correspondence is to be directed. E-mail: ivan.horak@up.ac.za

1 Department of Veterinary Tropical Diseases, Faculty of Veterinary Science, University of Pretoria, Private Bag X04, Onderstepoort, 0110 South Africa; and Department of Zoology and Entomology, University of the Free State, P.O. Box 339, Bloem fontein, 9300 South Africa

2 Döhne Agricultural Development Institute, Private Bag X15, Stutterheim, 4930 South Africa, and Department of Veterinary Tropical Diseases, Faculty of Veterinary Science, University of Pretoria, Private Bag X04, Onderstepoort, 0110 South Africa

3 Direcção de Ciências Animais, Instituto de Investigação Agrária de Mozambique, C.P. 1922, Maputo, Mozambique; and Department of Veterinary Tropical Diseases, Faculty of Veterinary Science, University of Pretoria, Private Bag X04, Onderstepoort, 0110 South Africa

4 Faculdade de Veterinária, Universidade Eduardo Mondlane, C.P. 257, Maputo, Mozambique

Accepted for publication 19 February 2009-Editor

\section{INTRODUCTION}

Various authors have documented the ixodid tick species infesting domestic animals and wildlife in South Africa (Theiler 1962; Walker 1991; Walker, Keirans \& Horak 2000). Furthermore, Theiler and her co-workers, in a series of papers published in the 1940s and 1950s, have plotted the specific localities at which many of these ticks were collected and Howell, Walker \& Nevill (1978) have converted the latter into maps. However, with the exception of the various Rhipicephalus spp. mapped by Walker et al. (2000), the published geographic distributions of many species that occur in South Africa are based on surveys conducted approximately 60 years ago (Theiler 1962). The ticks infesting domestic and wild animals in Mozambique have also been well documented (Theiler 1943, 1962; Tendeiro 1954; Dias 
1993), but their geographic distributions are largely unknown.

Some of the more recent data for the Eastern Cape Province is that of Baker (1982), who summarized the results of acaricide resistance studies he and his co-workers had conducted, and plotted the localities in the eastern region of the Eastern Cape Province at which resistant strains of various tick species had been collected. Latterly Nyangiwe, Horak \& Bryson (2006) collected ticks from dogs at 40 localities in this region and plotted the distributions of four of the eight species that they had recovered. In Maputo Province Neves, Afonso \& Horak (2004) and De Matos, Sitoe, Neves, Bryson \& Horak (2008) collected ten species of ticks from dogs and plotted the distribution of two of these. To our knowledge no other recent data are available for these regions.

Walker (1991) listed 77 species of ixodid ticks that occur in South Africa, and two new species, Rhipicephalus oreotragi and Rhipicephalus warburtoni have subsequently been added to the list (Walker et al. 2000). Thirty-seven of these ticks have been recorded on domestic animals. The names of two of these 37 species, namely Haemaphysalis leachi and Hyalomma marginatum turanicum, neither of which occur in South Africa, have been reinstated as Haemaphysalis elliptica and Hyalomma glabrum, both of which are valid indigenous species (Apanaskevich \& Horak 2006; Apanaskevich, Horak \& Camicas 2007). A third species, Hyalomma marginatum rufipes has recently been raised to species level, namely Hyalomma rufipes (Apanaskevich \& Horak 2008).

Dias (1993) recorded 59 ixodid tick species in Mozambique, and listed 26 of these as parasitizing domestic animals. Of the latter 26 species Amblyomma theilerae has been synonymized with Amblyomma hebraeum (Camicas, Hervy, Adam \& Morel 1998), Haemaphysalis humerosoides is considered a synonym of Haemaphysalis leachi (Camicas et al. 1998), and Rhipicephalus reichenowi is considered a synonym of Rhipicephalus planus (Walker et al. 2000). We now also know that the tick Dias identified as Rhipicephalus capensis does not occur in Mozambique and, although he listed Rhipicephalus sanguineus from cattle, in our opinion the latter tick is more likely to be Rhipicephalus turanicus. The recent surveys of Neves et al. (2004) and De Matos et al. (2008) have added $H$. elliptica, Haemaphysalis spinulosa, Ixodes cavipalpus, a Rhipicephalus sp. (near $R$. pravus) and $R$. turanicus to the species listed by Dias (1993).
Several of Dias' studies on the ticks of Mozambique commenced more than 50 years ago and although he probably listed nearly all the species that occur there, he unfortunately did not always record the localities at which particular species were collected. Furthermore, the civil war that ended during the 1990s and its consequences for humans, livestock and wildlife, plus the livestock restocking programme that followed, have probably all had an effect on the species composition and geographic distribution of ticks in Mozambique. Thus with the exception of the surveys conducted by Neves et al. (1994) and De Matos et al. (2008), there is little current information on the ticks that occur there.

The present studies were undertaken in an attempt to rectify this situation for both the eastern region of the Eastern Cape Province, South Africa and for Maputo Province, the most southerly of the ten provinces of Mozambique. At the same time this provided the opportunity to compare the species composition of ticks infesting cattle, goats and dogs in a temperate region with that of ticks infesting the same host species in a subtropical region, both with long coastlines.

\section{MATERIALS AND METHODS}

\section{Localities}

During 2004 and 2005 ticks were collected from cattle, goats, dogs and the vegetation at 72 localities in the eastern region of the Eastern Cape Province, South Africa. This region lies between $30^{\circ} 22^{\prime}$ and $32^{\circ} 39^{\prime} \mathrm{S}$, and $27^{\circ} 45^{\prime}$ and $29^{\circ} 55^{\prime} \mathrm{E}$, and the terrain rises from sea level in the south to approximately $2000 \mathrm{~m}$ in the north-east in the Drakensberg mountain range. Its inland climate is classified as that of plateau slopes, and its approximately $250 \mathrm{~km}$ long Indian Ocean seaboard has a subtropical coastal climate. Summer rainfall varies between 500 and $1000 \mathrm{~mm}$ annually, and winter rainfall between 125 and $375 \mathrm{~mm}$. Midsummer mean daily temperatures vary between $15.0^{\circ} \mathrm{C}$ and $25.0^{\circ} \mathrm{C}$ and those of midwinter between $7.5^{\circ} \mathrm{C}$ and $17.5^{\circ} \mathrm{C}$. The vegetation along the coast is described as Coastal Forest and Thornveld. Adjacent to the latter in the west lies a strip of vegetation described as Eastern Province Thornveld and in the east a strip described as Ngongoni Veld. With the exception of ribbons of Valley Bushveld along rivers courses, the inland vegetation, including that in the mountainous north, is described as Highland Sourveld (Acocks 1988).

In 2004, 2005 and 2006 ticks were also collected at 30 localities spread throughout Maputo Province, 
Mozambique, from the same host species as in the Eastern Cape Province, and from the vegetation. The southern boundary of this province is approximately $500 \mathrm{~km}$ north-east of the northern limit of the Eastern Cape Province survey region. Maputo Province is located between $24^{\circ} 15^{\prime}$ and $26^{\circ} 52^{\prime} \mathrm{S}$, and $31^{\circ} 48^{\prime}$ and $33^{\circ} 05^{\prime} \mathrm{E}$, and has a climate classified as subtropical lowveld. Its coastline is approximately $320 \mathrm{~km}$ long, and the landscape rises from the Indian Ocean in the east to about $800 \mathrm{~m}$ above sea level in the Lebombo mountain range in the west. Annual summer rainfall varies between 500 and $750 \mathrm{~mm}$ and winter rainfall between 125 and $250 \mathrm{~mm}$. Midsummer mean daily temperatures vary between $25.0^{\circ} \mathrm{C}$ and $27.5^{\circ} \mathrm{C}$ and midwinter temperatures between $15.0^{\circ} \mathrm{C}$ and $20.0^{\circ} \mathrm{C}$. The vegetation along the coast is described as shrubland with patches of wetland, mangrove and deciduous trees along riverbanks and dunes. Inland it is dominated by woodland and associations of savannah and mopane (Colophospermum mopane) in the north-west district of Magude. The inland vegetation in the south is dominated by forest from the mountain district of Namaacha to the southern Mozambican border.

\section{Animals}

Whenever possible, ticks were collected from five approximately year-old cattle, five goats and five dogs at each of the sampling sites (Nyangiwe et al. 2006; Nyangiwe \& Horak 2007; De Matos et al. 2008). However, the prescribed numbers of animals at the stipulated number of localities were not always realised. In addition, ticks were collected from 24 dogs at two villages in south-west Maputo Province during a rabies inoculation campaign, as well as from two dogs at two villages in the south-east of the province (De Matos et al. 2008). The geographic coordinates of each site at which ticks were collected were recorded and used to plot the distributions of the various tick species.

\section{Tick collections}

Ticks were collected from the ears, bodies, bellies, feet, tails and peri-anal regions of the cattle and goats on the single occasion that each locality was visited. To minimize stress to the dogs as well as injuries to the researchers, they were often muzzled and thereafter restrained by their owners. The collections of ticks from the animals were not intended to be exhaustive, and focused mainly on adult ticks, but several nymphs of $A$. hebraeum and Rhipicephalus appendiculatus were also collected. In addition, questing ticks were collected by dragging flannel strips over the vegetation as described by Horak, Gallivan, Spickett \& Potgieter (2006), for a distance of $100 \mathrm{~m}$ at three places close to each of the collection sites. The ticks recovered from the animals and the flannel strips were placed in $70 \%$ ethyl alcohol in internally labelled vials and transported to laboratories in South Africa or Maputo, where they were identified and counted using stereoscopic microscopes.

\section{RESULTS AND DISCUSSION}

A total of 11 ixodid tick species and one argasid species were recovered in the eastern region of the Eastern Cape Province (Table 1), and 15 ixodid tick species in Maputo Province (Table 2). Amblyomma hebraeum, Rhipicephalus (Boophilus) microplus, $R$. appendiculatus and Rhipicephalus evertsi evertsi were most prevalent on cattle, goats and the vegetation, and $H$. elliptica on dogs in both provinces (Tables1 and 2). Furthermore, a large number of cattle and dogs in Maputo Province were infested with Rhipicephalus simus (Table 2).

\section{Amblyomma hebraeum}

This tick was present mainly in the coastal region of the eastern part of the Eastern Cape Province, where the vegetation is described as Coastal Forest and Thornveld interspersed with Valley Bushveld (Acocks 1988). However, a considerable number of collections were also made further inland (Fig. 1A). With the above mentioned exception, the distribution of $A$. hebraeum in the survey region in the Eastern Cape Province is similar to that plotted for it by Howell et al. (1978). Estrada-Peña, Horak \& Petney (2008) noted that a trend towards more intense periods of drought in the highveld of Zimbabwe favoured the expansion of $A$. hebraeum in this region of that country and that temperature did not have an effect on this expansion. A similar phenomenon could be responsible for the spread of this tick into the higher lying areas of the Eastern Cape Province.

Amblyomma hebraeum was widespread throughout Maputo Province (Fig. 1B). This widespread distribution complements its extensive distribution in South Africa to the south and west of this province as illustrated by Howell et al. (1978) and Walker \& Olwage (1987).

\section{Haemaphysalis elliptica}

When the surveys of Neves et al. (2004) and Nyangiwe et al. (2006) on the ticks of dogs in Mozambique 

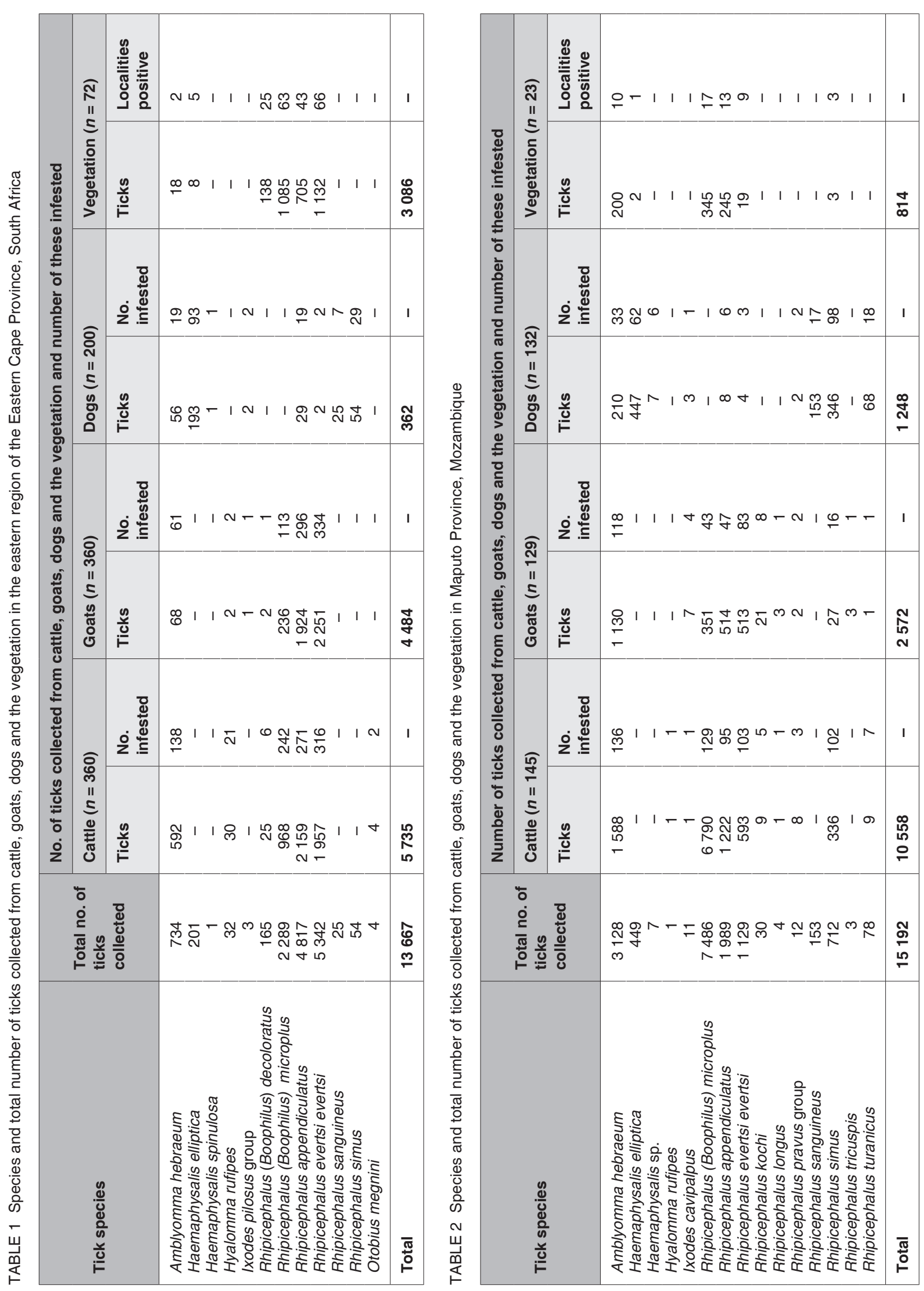

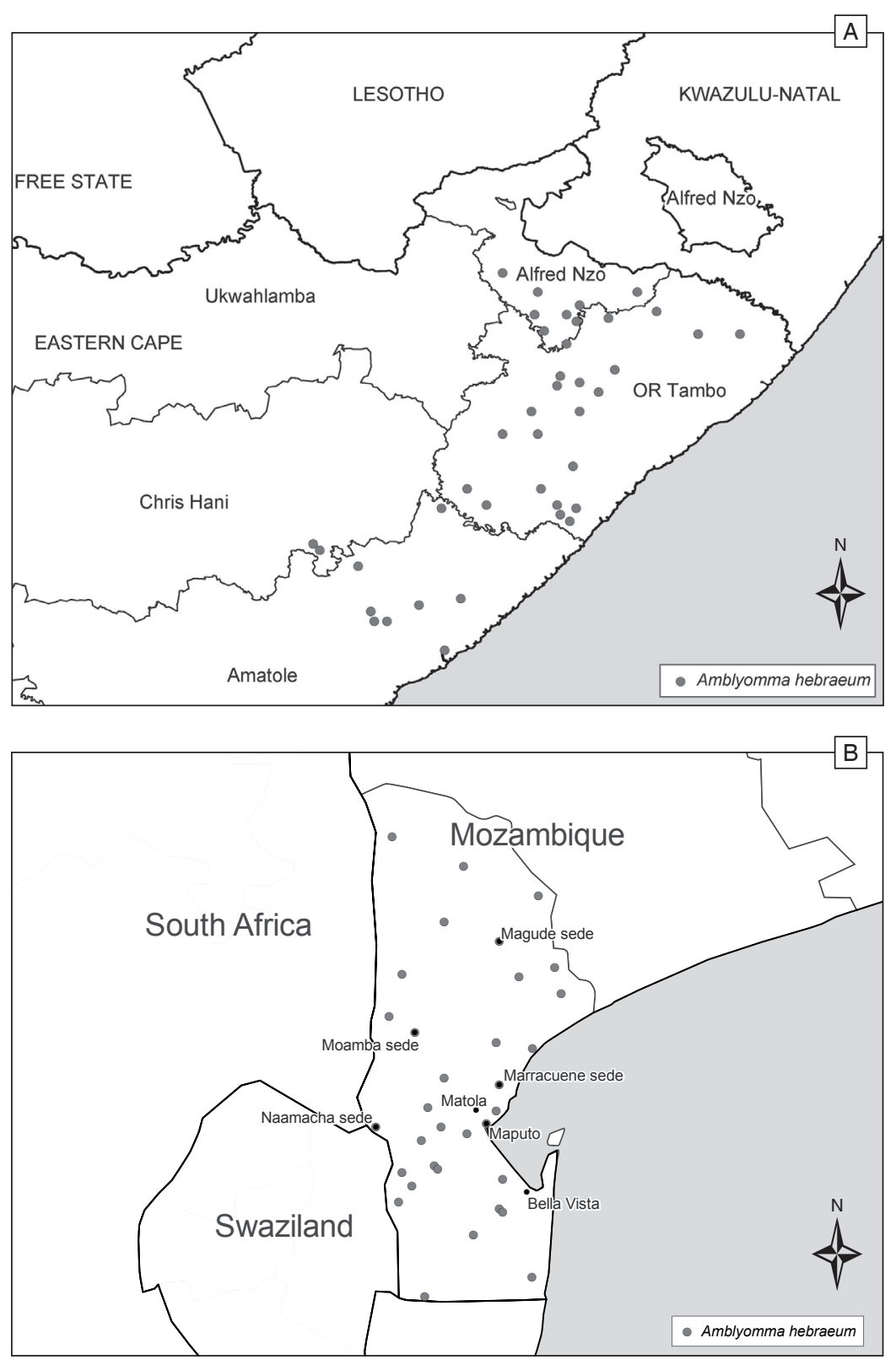

FIG. 1

The geographic distribution of Amblyomma hebraeum in $(A)$ the eastern region of the Eastern Cape Province, South Africa, and (B) Maputo Province, Mozambique and in the Eastern Cape Province were published this tick was referred to as $H$. leachi. It has subsequently been re-established as an old taxon, namely $H$. elliptica, originally described by Koch in 1844 from the Cape of Good Hope (Apanaskevich et al. 2007). Nyangiwe et al. (2006) and De Matos et al. (2008) have plotted the geographic distribution of $H$. elliptica in the eastern region of the Eastern Cape Province and in Maputo Province and these maps will not be repeated here. Although collections were made at only 20 of the 40 localities at which dogs were examined in the Eastern Cape Province, these were spread nearly throughout the survey region, leading us to believe that the tick is as widespread in this region as illustrated by Howell et al. (1978). In Maputo Province it was collected at 26 of the 27 localities at which dogs were examined.

Norval (1984) has suggested that wherever there are dogs and adequate numbers of rodents to act as hosts for its immature stages, $H$. leachi $(H$. elliptica) is likely to be present. The distribution map of Howell et al. (1978) portrays a more extensive distribution for H. leachi (H. elliptica) in the east of South Africa, adjacent to Mozambique, than in the west of the former country. The widespread distribution of $H$. elliptica in Maputo Province thus supplements the already extensive distribution of this tick in the southeast of the sub-continent. 


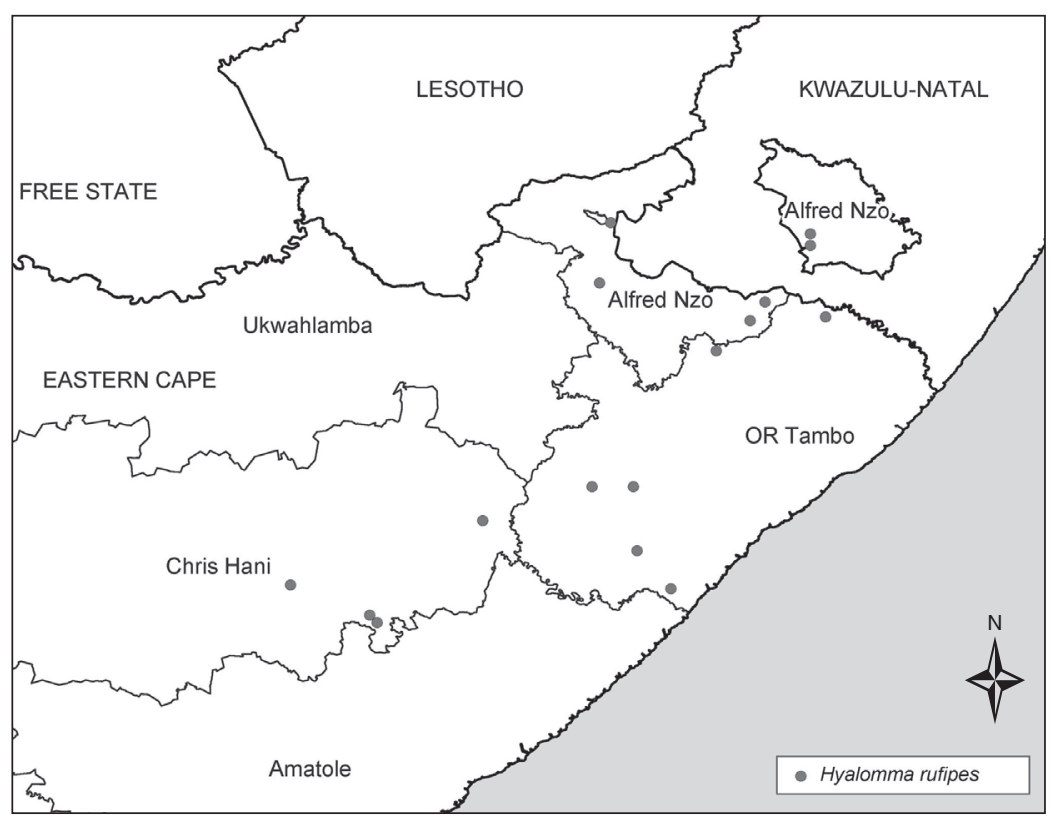

FIG. 2

The geographic distribution of Hyalomma rufipes in the eastern region of the Eastern Cape Province, South Africa

\section{Hyalomma spp.}

Hyalomma rufipes was present at 16 localities in the Eastern Cape Province (Fig. 2), and its distribution in this region is similar to that mapped for it by Howell et al. (1978). Walker (1991) states that $H$. rufipes is absent in many of the moister eastern regions of South Africa. Its presence in the Eastern Cape survey region may thus reflect a trend towards slightly drier conditions in this area.

Hyalomma rufipes was collected at only one locality in Maputo Province. This is not surprising, as its distribution as illustrated by Howell et al. (1978), shows that it is not present in north-east KwaZulu-Natal or in the Kruger National Park, South Africa, immediately to the south and to the west of Maputo Province. Furthermore, Dias (1993) states that the distribution of $H$. rufipes is restricted to the drier regions of some of the more northerly provinces of Mozambique, namely Inhambane, Sofala, Tete and Niassa.

No Hyalomma truncatum were collected in either of the survey regions. The north-eastern limits of this tick's distribution in South Africa appear to coincide with the Lebombo mountain range that lies between the Kruger National Park in the west and Maputo Province in the east (Howell et al. 1978). During the cooler months of the year nearly every scrub hare, Lepus saxatilis, in the Kruger National Park is infested with the immature stages of $H$. truncatum (Horak, Spickett, Braack \& Penzhorn 1993), and most giraffes, Giraffa camelopardalis, with adults throughout the year (Horak, Golezardy \& Uys 2007).

\section{Ixodes spp.}

Three ticks belonging to the Ixodes pilosus group of species were recovered at three sampling sites in the Eastern Cape Province, one from a goat and one each from two dogs. These collection localities lie within the distribution range mapped for this group of ticks by Howell et al. (1978). Eleven Ixodes cavipalpus were collected from a calf, four goats and a dog at a single locality in Maputo Province. Although Dias (1993) listed five species of Ixodes that occur in Mozambique, he did not include I. cavipalpus amongst these. According to Walker (1991) the latter tick is possibly the most widely distributed Ixodes sp. in the Afrotropical region, and has been collected from a wide variety of hosts (Theiler 1962).

\section{Rhipicephalus (Boophilus) spp.}

Rhipicephalus (B.) decoloratus was collected at 29 of the 72 survey localities in the Eastern Cape Province (Fig. 3A), compared to not one of the 30 localities in Maputo Province. Conversely R. (B.) microplus was present at nearly every sampling locality in both provinces (Fig. 3B, C).

Howell et al. (1978) mapped the distributions of both these ticks in South Africa. At that time R. (B.) decoloratus was widespread in the eastern region of the Eastern Cape Province, whereas the distribution of $R$. (B.) microplus was restricted to coastal pockets. Using their own more recently obtained data, Baker, Jordaan \& Robertson (1981) and Baker (1982) illustrated a considerably more extensive 

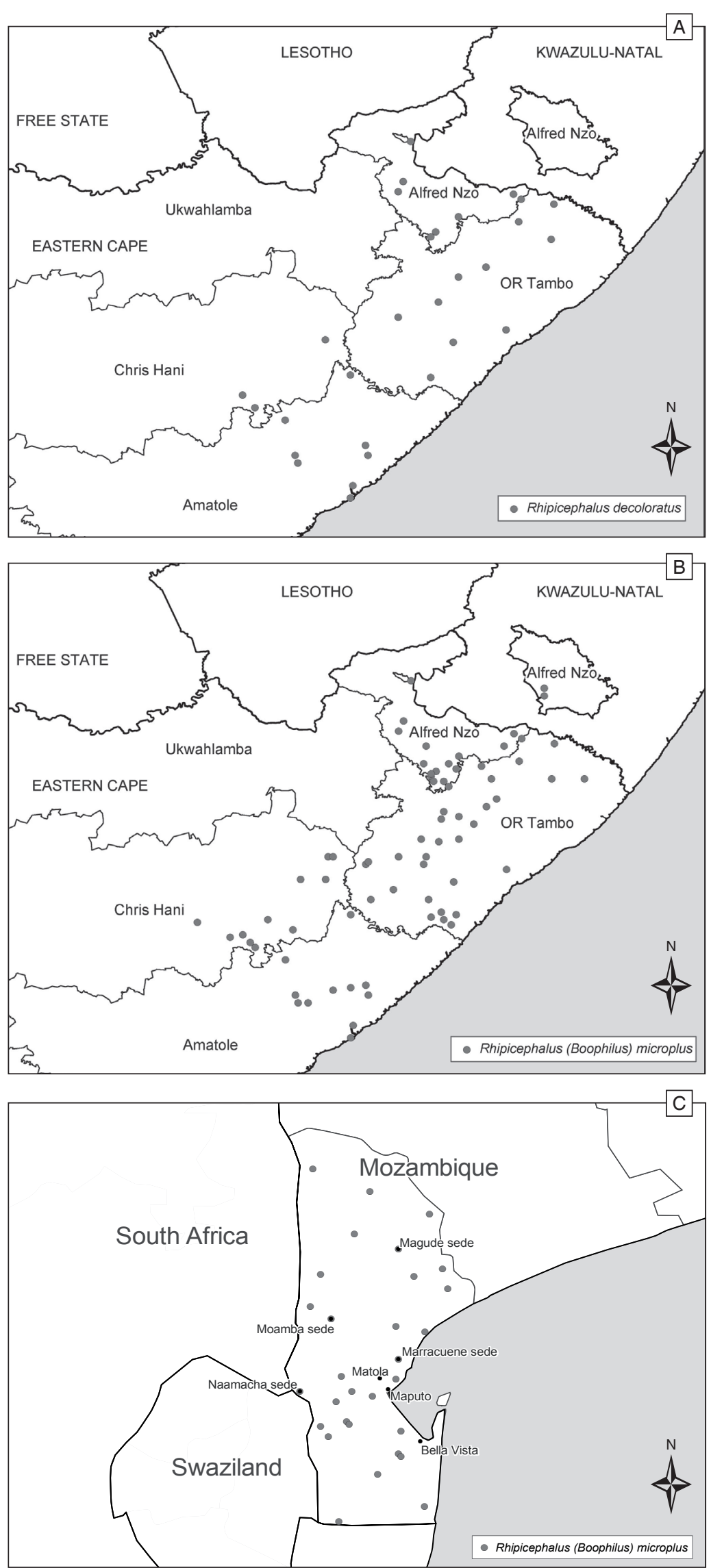

FIG. 3

The geographic distribution of Rhipicephalus (Boophilus) decoloratus in (A) the eastern region of the Eastern Cape Province, South Africa, and of Rhipicephalus (Boophilus microplus in (B) the eastern region of the Eastern Cape Province and (C) Maputo Province 
distribution for the latter tick in this region. The results of the present survey indicate that $R$. (B.) microplus has further extended its range, and that the 1978 distribution pattern of the two ticks has now been reversed. In the present study a single nymph and 26 adult $R$. (B.) decoloratus were collected from six cattle and a goat at four localities in the Eastern Cape Province, and questing larvae from the vegetation at 25 localities. In contrast 16 nymphs and 1288 adult $R$. (B.) microplus were collected from 242 cattle and 113 goats at 69 of the 72 localities surveyed, and 1085 larvae from the vegetation at 62 localities in this province.

At the time Dias (1993) compiled his lists of the ticks of Mozambique he stated that $R$. (B.) decoloratus was common wherever there were cattle, in all regions of the country, and that it was also present on several wild mammals. In support of this observation greater kudus, Tragelaphus strepsiceros, and impalas, Aepyceros melampus, in the Kruger National Park, South Africa, to the west of Maputo Province, harbour very large numbers of $R$. (B.) decoloratus and no R. (B.) microplus (Horak, Boomker, Spickett \& De Vos 1992; Horak, Gallivan, Braack, Boomker \& De Vos 2003). This implies that in earlier times wildlife and probably also domestic cattle in Maputo Province were very likely to have been infested with $R$. (B.) decoloratus. This is no longer the case for domestic stock, as it appears as if the latter tick has now been displaced by $R$. (B.) microplus. Displacement has also been reported in Zimbabwe (Mason \& Norval 1980), the Eastern Province of Zambia
(Berkvens, Geysen, Chaka, Madder \& Brandt 1998) and Tanzania (Lynen, Zeman, Bakuname, Di Giulio, Mtui, Sanka \& Jongejan 2008).

The reasons for this displacement are numerous. The total length of the life cycle of $R$. (B.) microplus is slightly shorter than that of $R$. (B.) decoloratus (Arthur \& Londt 1973; Londt \& Arthur 1975), and female $R$. (B.) microplus produce slightly more eggs than those of $R$. (B.) decoloratus (Spickett \& Malan 1978). Its spread may thus be enhanced by its slightly shorter life cycle and slightly higher egg production. Moreover, cross mating between the two species results in sterile eggs being produced (Spickett \& Malan 1978), and although male ticks prefer to mate with conspecific females (Norval \& Sutherst 1986), they will also mate with females of the other species (Spickett \& Malan 1978). The males of $R$. (B.) microplus are sexually mature a few days sooner than those of $R$. (B.) decoloratus (Londt \& Arthur 1975), and thus in mixed infestations they have a greater chance of mating with females of their own species. Furthermore, if the sex ratio of male to female $R$. (B.) microplus is similar to that of $R$. (B.) decoloratus on naturally infested hosts, viz. approximately 2:1 (Horak et al. 1992, 2003), the excess numbers of $R$. (B.) microplus males could mate with $R$. (B.) decoloratus females, rather than the converse happening. As females apparently mate only once, the cross-mated females would produce sterile eggs and $R$. (B.) microplus would consequently constitute an ever-increasing proportion of future mixed populations of the two ticks.

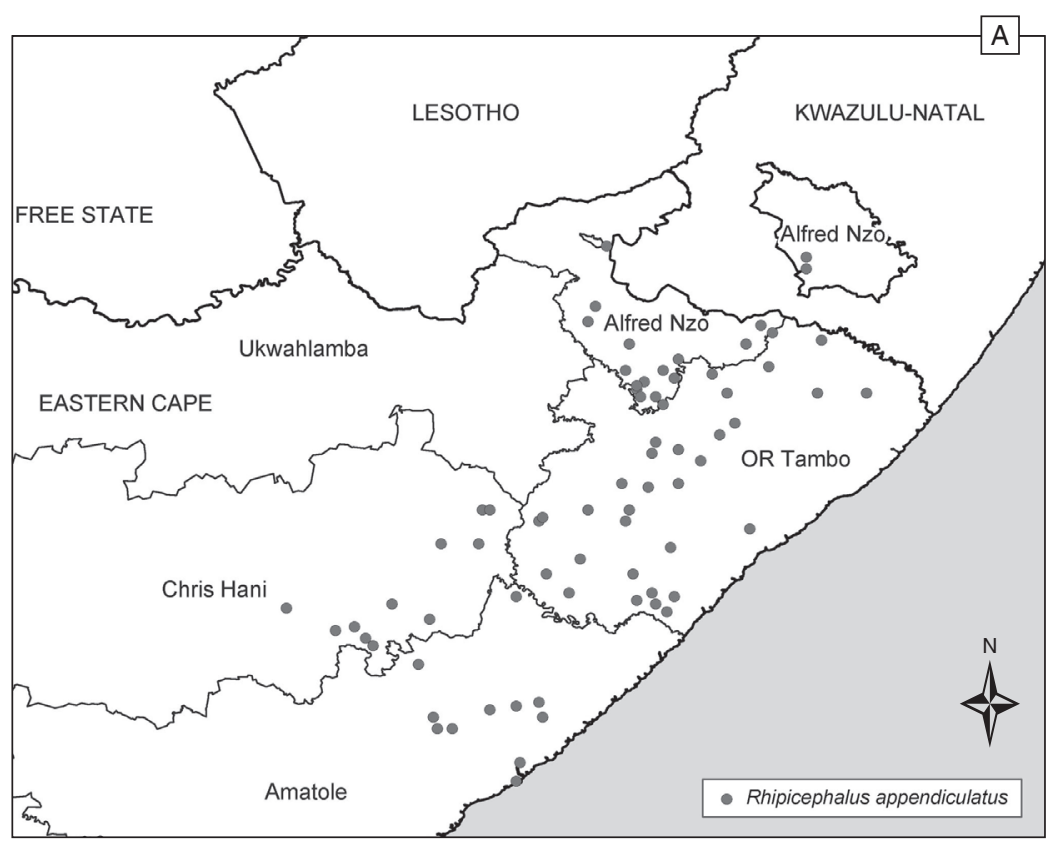

FIG. 4

The geographic distribution of Rhipicephalus appendiculatus in (A) the eastern region of the Eastern Cape Province, South Africa and (B) Maputo Province, Mozambique, and of Rhipicephalus evertsi evertsi in (C) the eastern region of the Eastern Cape Province and (D) Maputo Province 


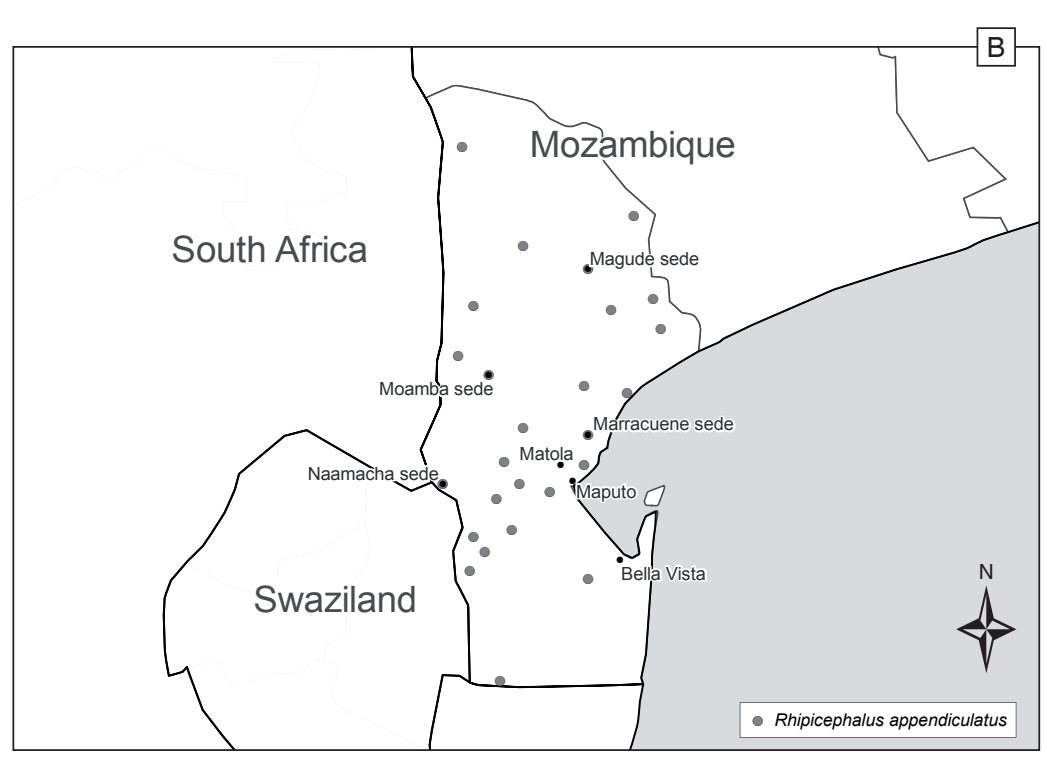

FIG. 4 (cont.)
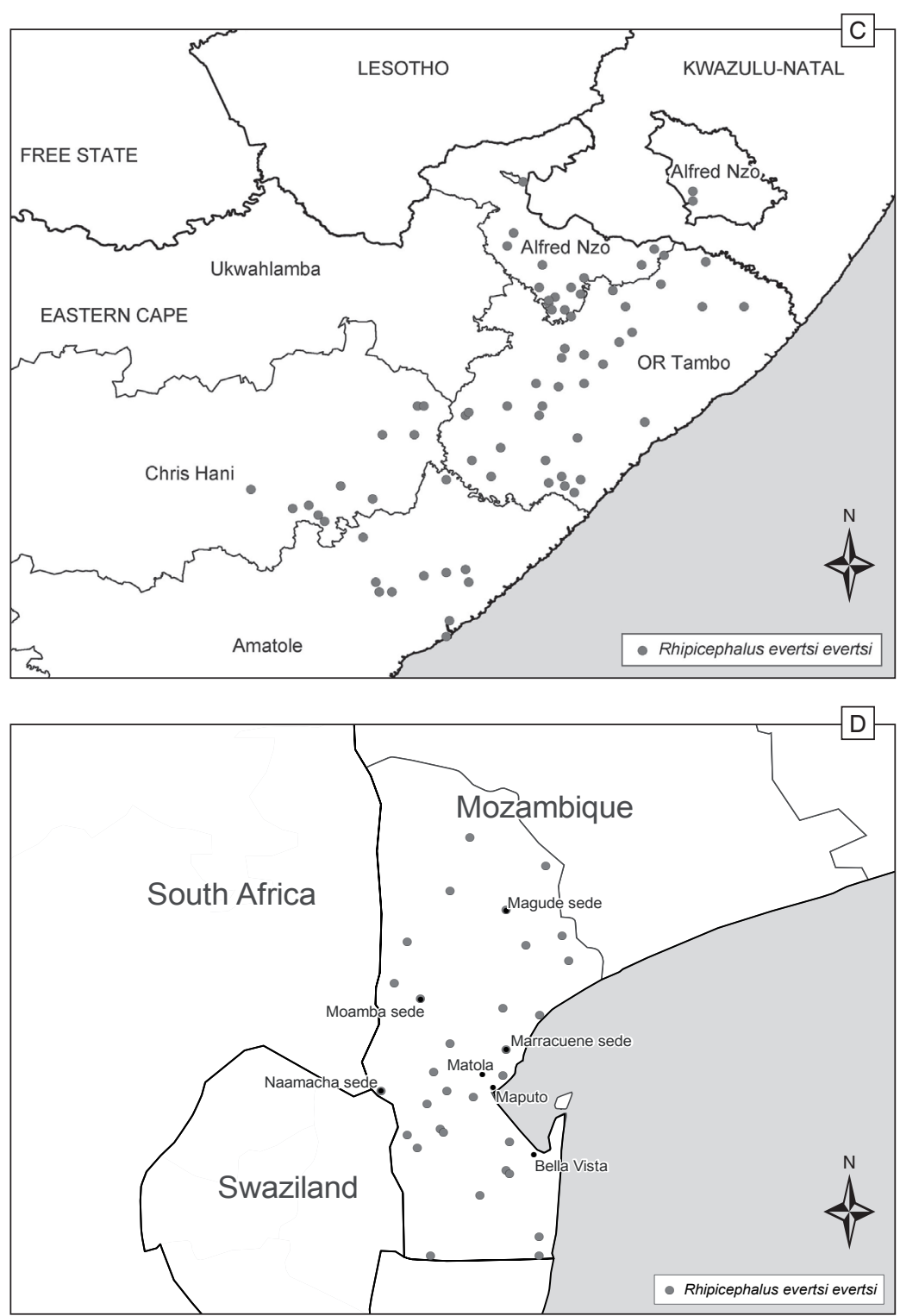
In southern Mozambique this displacement has been augmented by the decimation of livestock and wildlife during the war of independence and the civil strife that followed. This alone possibly led to the near extinction of $R$. (B.) decoloratus in this region. When restocking with cattle commenced after the war, $R$. (B.) microplus was probably introduced or reintroduced on these animals, whereas few of the larger wildlife species, and with them $R$. (B.) decoloratus, have returned to Maputo Province.

\section{Rhipicephalus appendiculatus}

This tick was collected at 70 of the 72 collection localities in the eastern region of the Eastern Cape Province (Fig. 4A) and, with the exception of the most southerly region of Maputo Province, where it was collected at only one locality, it was also widespread throughout Maputo Province (Fig. 4B).

Its distribution in South Africa, as illustrated by Walker et al. (2000), indicates that it is absent, or only sparsely present, in north-east KwaZulu-Natal, where this province abuts on the southern border of Maputo Province. The tick's scant distribution in north-east South Africa thus supports its sparseness or absence in the south of Maputo Province. Its widespread presence in the remainder of Maputo Province adds this region to its already widespread distribution in south-east Africa.

\section{Rhipicephalus evertsi evertsi}

Rhipicephalus evertsi evertsi is widespread throughout both survey regions (Fig. 4C, D), confirming its position as one of the most widely distributed Rhipicephalus species in sub-Saharan Africa (Walker et al. 2000). Although domestic and wild equids are probably the preferred hosts of all stages of development of this tick (Norval 1981), cattle, goats and sheep are also good hosts, while dogs are seldom infested (Walker et al. 2000). This pattern of host infestation is also apparent in the present surveys (Tables 1, 2).

The tick distribution maps published by Walker et al. (2000) for Rhipicephalus spp. in sub-Saharan Africa, illustrate the widespread distribution of $R$. e. evertsi in the eastern half of South Africa, but do not include a single site in southern Mozambique. This we are sure is due to a lack of reportage and not actual absence. Its presently recorded widespread distribution in Maputo Province (Fig. 4D), complements its distribution in the adjacent regions of South Africa (Walker et al. 2000).

\section{Rhipicephalus kochi}

This tick has a very limited distribution in South Africa. It is present only in the far north-east regions of KwaZulu-Natal and Limpopo Provinces where these border on Mozambique (Walker et al. 2000), and it is thus usually only encountered on wild animals in South Africa. It was collected from cattle and goats in Maputo Province within the distribution range recorded for it in this region by Walker et al. (2000).

\section{Rhipicephalus pravus group}

This group of ticks comprises several apparently closely related species. All stages of development of some of these have been illustrated and described (Walker et al. 2000), whereas others remain innominate and undescribed.

One of the latter ticks has been designated Rhipicephalus sp. (near pravus) and its distribution stretches across southern Africa from northern $\mathrm{Na}$ mibia in the west, through Botswana and northern South Africa to southern Mozambique in the east (Walker et al. 2000), while the distribution of another, designated Rhipicephalus sp. (near punctatus) extends from south-western Angola in the west, through Zambia and Zimbabwe to northern Mozambique in the east (Walker et al. 2000). The tick collected in Maputo Province resembles the Rhipicephalus sp. (near pravus) entity, and its distribution corresponds with that of the latter tick as illustrated by Walker et al. (2000). Adult ticks of this species infest a variety of domestic and wild hosts, including hares, and the immature stages infest elephant shrews and hares (Walker et al. 2000). In the present survey three cattle, two goats and two dogs were infested with adult ticks (Table 2).

\section{Rhipicephalus sanguineus}

All stages of development of $R$. sanguineus are nearly exclusively parasites of domestic dogs (Walker et al. 2000), and adult ticks were collected only from dogs in both survey regions, at two localities in the Eastern Cape Province and at eight in Maputo Province (Fig. 5A). The free-living stages of this tick's life cycle have adapted to the environment in and around the resting places of dogs in man-made structures such as sheds, dog kennels and human dwellings, whence they quest for their hosts (Horak 1982; Walker et al. 2000). Its presence on dogs at ten of the rural sampling localities in the present surveys suggests that these animals were, at least for some 

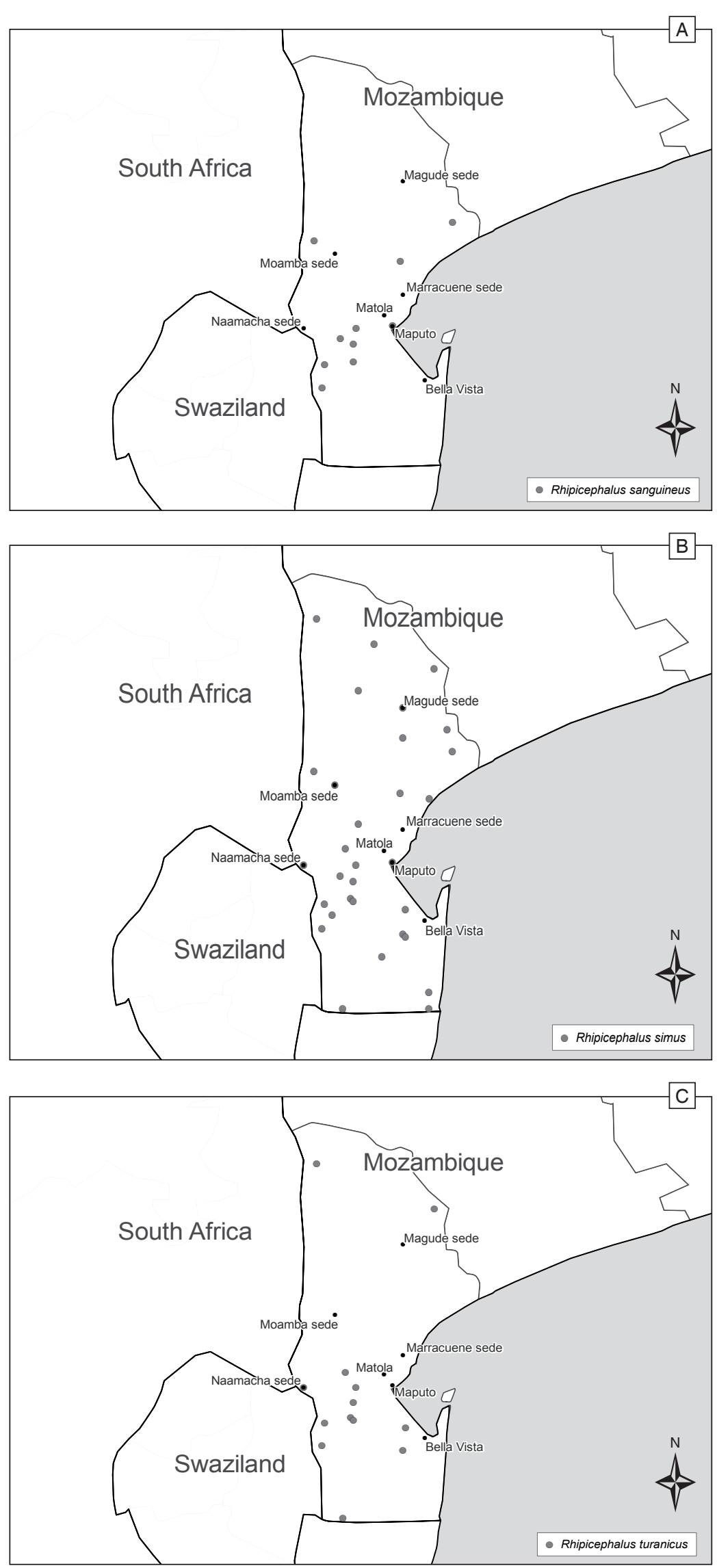

FIG. 5

Geographic distribution of (A) Rhipicephalus sanguineus, (B) Rhipicephalus simus, and (C) Rhipicephalus turanicus in Maputo Province, Mozambique 
part of the day, chained, or caged at the homes of their owners, or that they had a preferred resting place in or next to these homes.

\section{Rhipicephalus simus}

Nyangiwe et al. (2006) and De Matos et al. (2008) have mapped the geographic distribution of $R$. simus in the eastern region of the Eastern Cape Province and in Maputo Province based on collections from dogs. Although R. simus is widespread in the moister regions of southern Africa, adult ticks are seldom collected in large numbers (Walker et al. 2000). In the eastern region of the Eastern Cape Province it was collected only from dogs, and then only from 14 of the 53 localities at which dogs were examined. Its absence on cattle in the Eastern Cape at the same localities at which infested dogs were present is difficult to explain. In contrast slightly more cattle than dogs were infested in Maputo Province, where $R$. simus was widespread and present at 24 of the 30 localities sampled (Fig. 5B).

The immature stages of this tick are reliant on rodents as hosts (Petney, Horak, Howell \& Meyer 2004), and Horak, Spickett \& Braack (2000) have recorded a significant increase in the numbers of questing adult $R$. simus on the vegetation in the southern Kruger National Park in the year following a rodent explosion at the same locality. The small number of hosts infested with adult $R$. simus in the Eastern Cape Province compared with the large number in Maputo Province could possibly reflect differences in both the overall abundance and species richness of the rodent fauna in the two regions.

\section{Rhipicephalus turanicus}

The inability to distinguish this tick from $R$. sanguineus has created many problems as to their identities, host preferences, life cycles and geographic distributions. The studies of Pegram, Clifford, Walker \& Keirans, (1987a) and Pegram, Keirans, Clifford \& Walker (1987b) have addressed this problem, but have, as yet, not solved it. This is probably mainly due to the widespread distributions of both of these ticks and with these the inevitable geographic variability in their morphology. In her review of the ixodid ticks of southern Africa Walker (1991) reported that $R$. turanicus was present in scattered localities in Transvaal Province, South Africa (a province that has now been divided into the four northern provinces of this country) and from Bergville in KwaZuluNatal Province. The newfound ability to identify this tick with greater certainty resulted in Walker et al.
(2000) recording it at 11 localities in South Africa 9 years later. It is now frequently collected in South Africa from dogs, hares and larger birds and also questing from the vegetation, but has as yet not been found in the Eastern Cape Province. A total of 78 adult $R$. turanicus was collected in Maputo Province, mainly from dogs, but cattle and a goat were also infested (Table 2). It was particularly prevalent in the central region of Maputo Province, but collections were also made in the far south and north of the province (Fig. 5C).

Questing adult ticks have been collected from the vegetation in the southern Kruger National Park, South Africa, to the west of Maputo Province, where they are most abundant during the late summer and autumn (Horak et al. 2000). As with R. simus the immature stages of this tick are reliant on rodents as hosts (Walker et al. 2000), and Horak et al. (2000) recorded an increase in the numbers of questing adult ticks on the vegetation in the Kruger National Park in the year after a rodent explosion. We assume that Dias (1993) did not recognize R. turanicus as a separate species and included it with $R$. sanguineus in his list of ticks for Mozambique.

\section{Rhipicephalus spp.}

A number of unconfirmed locality records for Rhipicephalus longus exist in central and northern Mozambique (Walker et al. 2000), and the present collection is the furthest south to date.

Rhipicephalus tricuspis has been reported in the northern provinces of South Africa and in central and northern Mozambique, with a single record just north of Maputo Province (Walker et al. 2000). Three ticks were collected from a single goat in Maputo Province in the present survey (Table 2).

\section{Otobius megnini}

A single calf, at each of two localities in the eastern region of the Eastern Cape Province, was infested with the nymphs of the argasid tick, Otobius megnini (Table 1). No argasid ticks were collected in Maputo Province.

\section{ACKNOWLEDGEMENTS}

We thank the various cattle, goat and dog owners for permission to collect ticks from their animals and for their assistance with these collections. Our sincere thanks go to Messrs K. Kogina, B. Zenani and Z.M. Nyangiwe, who assisted with the tick collec- 
tions in the Eastern Cape Province, and Mr C. Sitoe for his assistance with the collections in Maputo Province. We are most grateful to the Directorates of Agriculture, Eastern Cape Province and of Animal Science, Mozambique, for permitting N. Nyangiwe and $\mathrm{C}$. de Matos to conduct the Eastern Cape and Mozambican segments of the study as part of their official duties. Dr Roy Williams, of the ARC-Onderstepoort Veterinary Institute, mapped the distributions of the ticks. The South African element of the project was financed by funds provided by Bayer HealthCare South Africa and by the Technology and Human Resources for Industry Programme (THRIP) of the Department of Trade and Industry, and the National Research Foundation. The finances for the Mozambican side came mainly from a SIDA/SARECJoint INEVE-Eduardo Mondlane University, Veterinary Faculty, Research Project, No. \# 27.

\section{REFERENCES}

ACOCKS, J.P.H. 1988. Veld types of South Africa with accompanying veld type map, $3^{\text {rd }}$ ed. (Memoirs of the Botanical Survey of South Africa, no. 57).

APANASKEVICH, D.A. \& HORAK, I.G. 2006. The genus HyaIomma Koch, 1844. I. Reinstatement of Hyalomma (Euhyalomma) glabrum Delpy, 1949 (Acari, Ixodidae) as a valid species with a redescription of the adults, the first description of its immature stages and notes on its biology. Onderstepoort Journal of Veterinary Research, 73:1-12.

APANASKEVICH, D.A., HORAK, I.G. \& CAMICAS, J-L. 2007. Redescription of Haemaphysalis (Rhipistoma) elliptica (Koch, 1844), an old taxon of the Haemaphysalis (Rhipistoma) leachi group from East and southern Africa, and of Haemaphysalis (Rhipistoma) leachi (Audouin, 1826) (Ixodida, Ixodidae). Onderstepoort Journal of Veterinary Research, 74: 181-208.

APANASKEVICH, D.A. \& HORAK, I.G. 2008. The genus Hyalomma Koch, 1844. V. Re-evaluation of the taxonomic rank of taxa comprising the $H$. (Euhyalomma) marginatum group of species (Acari: Ixodidae) with redescription of all parasitic stages and notes on biology. International Journal of Acarology, 34:13-42.

ARTHUR, D.R. \& LONDT, J.G.H. 1973. The parasitic life cycle of Boophilus decoloratus (Koch, 1844). Journal of the Entomological Society of Southern Africa, 36:87-116.

BAKER, J.A.F., JORDAAN, J.O. \& ROBERTSON, W.D. 1981. A comparison of the resistance spectra to ixodicides of Boophilus decoloratus (Koch) and Boophilus microplus (Canestrini) in the Republic of South Africa and Transkei, in Proceedings of an International Conference on Tick Biology and Control, Rhodes University, Grahamstown, South Africa, 2729 January 1981, edited by G.B. Whitehead \& J.D. Gibson: 103-108.

BAKER, J.A.F. 1982. Some thoughts on resistance to ixodicides by ticks in South Africa, in Proceedings of a Symposium on Ectoparasites of Cattle, South African Bureau of Standards, Pretoria, South Africa, 15 and 16 March 1982: 52-67.

BERKVENS, D.L., GEYSEN, D.M., CHAKA, G., MADDER, M. \& BRANDT, J.R.A. 1998. A survey of the ixodid ticks parasitis- ing cattle in The Eastern Province of Zambia. Medical and Veterinary Entomology, 12:234-420.

CAMICAS, J-L., HERVY, J-P., ADAM, F. \& MOREL, P-C. 1998. The ticks of the World (Acarida, Ixodida). Nomenclature, described stages, hosts, distribution. Paris: Orstom Editions.

DE MATOS, C., SITOE, C., NEVES, L., BRYSON, N.R. \& HORAK, I.G. 2008. Ixodid ticks on dogs belonging to people in rural communities and villages in Maputo Province, Mozambique. Onderstepoort Journal of Veterinary Research, 75:103-108.

DIAS, J.A. TRAVASSOS SANTOS. 1993. Some data concerning the ticks (Acarina-Ixodoidea) presently known in Mozambique. Garcia de Orta, Séries Zoologica, Lisboa, 18(1991): 27-48.

ESTRADA-PEÑA, A., HORAK, I.G. \& PETNEY, T.N. 2008. Changes in climate and their suitability for the ticks Amblyomma hebraeum and Amblyomma variegatum (Ixodidae) in Zimbabwe (1974-1999). Veterinary Parasitology, 151:256267.

HORAK, I.G. 1982. Parasites of domestic and wild animals in South Africa. XIV. The seasonal prevalence of Rhipicephalus sanguineus and Ctenocephalides spp. on kennelled dogs in Pretoria North. Onderstepoort Journal of Veterinary Research, 49:63-68.

HORAK, I.G., BOOMKER, J., SPICKETT, A.M. \& DE VOS, V. 1992. Parasites of domestic and wild animals in South Africa. XXX. Ectoparasites of kudus in the eastern Transvaal Lowveld and the eastern Cape Province. Onderstepoort Journal of Veterinary Research, 59:259-273.

HORAK, I.G., SPICKETT, A.M., BRAACK, L.E.O. \& PENZHORN, B.L. 1993. Parasites of domestic and wild animals in South Africa. XXXII. Ixodid ticks on scrub hares in the Transvaal. Onderstepoort Journal of Veterinary Research, 60:163-174.

HORAK, I.G., SPICKETT, A.M. \& BRAACK, L.E.O. 2000. Fluctuations in the abundance of Boophilus decoloratus and three Rhipicephalus species on vegetation during eleven consecutive years. Proceedings of the Third International Conference on Ticks and Tick-borne Pathogens: into the $21^{\text {st }}$ Century, edited by M. Kazimírová, M. Labuda \& P.A. Nuttall. Bratislava, Slovakia: Institute of Zoology, Slovak Academy of Sciences: 247-251.

HORAK, I.G., GALLIVAN, G.J., BRAACK, L.E.O., BOOMKER, J. \& DE VOS, V. 2003. Parasites of domestic and wild animals in South Africa. XLI. Arthropod parasites of impalas (Aepyceros melampus) in the Kruger National Park. Onderstepoort Journal of Veterinary Research, 70:131-163.

HORAK, I.G., GALLIVAN, J., SPICKETT, A.M. \& POTGIETER, A.L.F. 2006. Effect of burning on the numbers of questing ticks collected by dragging. Onderstepoort Journal of Veterinary Research, 73:163-174.

HORAK, I.G., GOLEZARDY, H. \& UYS, A.C. 2007. Ticks associated with the three largest wild ruminant species in southern Africa. Onderstepoort Journal of Veterinary Research, 74: 231-242.

HOWELL, C.J., WALKER, JANE B. \& NEVILL, E.M. 1978. Ticks, mites and insects infesting domestic animals in South Africa. Part 1. Descriptions and biology. Pretoria, Republic of South Africa: Department of Agricultural Technical Services (Science Bulletin, no. 393).

LONDT, J.G.H. \& ARTHUR, D.R. 1975. The structure and parasitic life cycle of Boophilus microplus (Canestrini, 1888) in South Africa (Acarina: Ixodidae). Journal of the Entomological Society of Southern Africa, 38:321-340. 
LYNEN, G., ZEMAN, P., BAKUNAME, C., DI GIULIO, G., MTUI, P., SANKA, P. \& JONGEJAN, F. 2008. Shifts in the distributional ranges of Boophilus ticks in Tanzania: evidence that a parapatric boundary between Boophilus microplus and $B$. decoloratus follows climate gradients. Experimental and Applied Acarology, 44:147-164.

MASON, C.A. \& NORVAL, R.A.I. 1980. The ticks of Zimbabwe. I. The genus Boophilus. Zimbabwe Veterinary Journal, 11:3643.

NEVES, L., AFONSO, SONIA \& HORAK, I.G. 2004. Ixodid ticks on dogs in and around Maputo and elsewhere in Mozambique. Onderstepoort Journal of Veterinary Research, 71:279-283.

NORVAL, R.A.I. 1981. The ticks of Zimbabwe. III. Rhipicephalus evertsi evertsi. Zimbabwe Veterinary Journal, 12:31-35.

NORVAL, R.A.I. 1984. The ticks of Zimbabwe. IX. Haemaphysalis leachi and Haemaphysalis spinulosa. Zimbabwe Veterinary Journal, 15:9-17.

NORVAL, R.A.I. \& SUTHERST, R.W. 1986. Assortative mating between Boophilus decoloratus and Boophilus microplus (Acari: Ixodidae). Journal of Medical Entomology, 23:459460.

NYANGIWE, N., HORAK, I.G. \& BRYSON, N.R. 2006. Ixodid ticks on dogs in the eastern region of the Eastern Cape Province, South Africa. Onderstepoort Journal of Veterinary Research, 73:305-309.

NYANGIWE, N. \& HORAK, I.G. 2007. Goats as alternative hosts of cattle ticks. Onderstepoort Journal of Veterinary Research, 74:1-7.

PEGRAM, R.G., CLIFFORD, C.M., WALKER, JANE B. \& KEIRANS, J.E. 1987a. Clarification of the Rhipicephalus sanguineus group (Acari, Ixodoidea, Ixodidae). I. R. sulcatus Neumann, 1908 and $R$. turanicus Pomarantsev, 1936. Systematic Parasitology, 10:3-26.
PEGRAM, R.G., KEIRANS, J.E., CLIFFORD, C.M. \& WALKER, JANE B. 1987b. Clarification of the Rhipicephalus sanguineus group (Acari, Ixodoidea, Ixodidae). II. R. sanguineus (Latreille, 1806) and related species. Systematic Parasitology, 10:27-44.

PETNEY, T.N., HORAK, I.G., HOWELL, D.J. \& MEYER, S. 2004. Striped mice, Rhabdomys pumilio, and other murid rodents as hosts for immature ixodid ticks. Onderstepoort Journal of Veterinary Research, 71:313-318.

SPICKETT, A.M. \& MALAN, J.R. 1978. Genetic incompatibility between Boophilus decoloratus (Koch, 1844) and Boophilus microplus (Canestrini, 1888) and hybrid sterility of Australian and South African Boophilus microplus (Acarina: Ixodidae). Onderstepoort Journal of Veterinary Research, 45:149-153.

TENDEIRO, J. 1954. An ixodological survey of Mozambique. Garcia de Orta, 3:231-236.

THEILER, GERTRUD. 1943. Notes on the ticks off domestic stock from Portuguese East Africa. Estação Anti-Malárica de Lourenço Marques: Imprensa Nacional de Moçambique.

THEILER, GERTRUD. 1962. The Ixodoidea parasites of vertebrates in Africa south of the Sahara (Ethiopian region). Project S 9958. Report to the Director of Veterinary Services, Onderstepoort. Mimeographed.

WALKER, JANE B. \& OLWAGE, A. 1987. The tick vectors of Cowdria ruminantium (Ixodoidea, Ixodidae, genus Amblyomma) and their distribution. Onderstepoort Journal of Veterinary Research, 54:353-379.

WALKER, JANE B. 1991. A review of the ixodid ticks (Acari, Ixodidae) occurring in southern Africa. Onderstepoort Journal of Veterinary Research, 58:81-105.

WALKER, JANE B., KEIRANS, J.E. \& HORAK, I.G. 2000. The genus Rhipicephalus (Acari, Ixodidae): a guide to the brown ticks of the world. Cambridge: Cambridge Academic Press. 